\title{
The implications of COP21 for our future climate
}

\author{
Corinne Le Quéré
}

Correspondence:

c.lequere@uea.ac.uk

Tyndall Centre for Climate Change

Research, University of East Anglia,

Norwich, Norfolk NR4 7TJ, UK

\section{Biomed Central}

\begin{abstract}
Rising $\mathrm{CO}_{2}$ in the atmosphere is the main cause of anthropogenic climate change, and the data shows a clear increase in global temperature of about $1{ }^{\circ} \mathrm{C}$ since preindustrial levels. Changes in climate extremes are also occurring, with observed increases in the frequency of heat waves, in intense precipitation (rainfall and snowfall) in many places, and in sea level and storm surges. A changing climate with rising extremes has associated risks for food production and other health-related impacts. In order to limit climate change well below $2{ }^{\circ} \mathrm{C}$, our carbon emissions must rapidly follow a decreasing trajectory to near zero.
\end{abstract}

Keywords: Climate change, $\mathrm{CO}_{2}$ emissions, Global warming, $\mathrm{COP} 21$, Health

\section{Background}

Let us start with the data. The increase in $\mathrm{CO}_{2}$ concentration in the atmosphere was first measured directly at Mauna Loa in Hawaii in 1958. The concentration has just crossed $400 \mathrm{ppm}$ (parts per million), an increase of $44 \%$ compared to the preindustrial levels (around year 1750).

Rising $\mathrm{CO}_{2}$ in the atmosphere is the main cause of anthropogenic climate change. To stop the planetary warming, $\mathrm{CO}_{2}$ concentration needs to stop rising. In turn to stop the rise in $\mathrm{CO}_{2}$ concentration, our carbon emissions must go down to near zero. It is thus no surprise that the global surface temperature has increased, by about $1{ }^{\circ} \mathrm{C}$ above pre-industrial levels. However, there are important inter-annual variations in global temperature that are caused by natural climate cycles. For example, the El Niño of 2015-2016 contributed to warming the climate recently, on top of the general trend due to $\mathrm{CO}_{2}$ and other greenhouse gases. It is clear though that the climate change trend dominates the recent warming, and our starting point is that human-induced climate change already cause about $1{ }^{\circ} \mathrm{C}$ warming. Keep this in mind when we speak about the objectives of the future.

\section{Main text}

Where do we stand as far as $\mathrm{CO}_{2}$ emissions are concerned? Emissions must decrease to near zero to stop the rise in atmospheric $\mathrm{CO}_{2}$ concentration. We have just published a report which shows that the global emissions of $\mathrm{CO}_{2}$ from fossil fuel burning have increased 2-3\% per year on average since the year 2000 [1]. However, the last year of emission data-2014-and our projection for this year-2015-suggest

(c) The Author(s). 2016 Open Access This article is distributed under the terms of the Creative Commons Attribution 4.0 International License (http://creativecommons.org/licenses/by/4.0/), which permits unrestricted use, distribution, and reproduction in any medium, provided you give appropriate credit to the original author(s) and the source, provide a link to the Creative Commons license, and indicate if changes were made. The Creative Commons Public Domain Dedication waiver (http://creativecommons.org/ publicdomain/zero/1.0/) applies to the data made available in this article, unless otherwise stated. 
that emission growth has stalled [2]. So a small pause in the long-term emission growth. We are expecting the global emissions to start growing once again, but may be not as fast they have grown since the year 2000. This is good news. The pause in the last 2 years is mainly due to the economic rebalancing in China, with a contribution from the very rapid deployment of renewable energies in the world-a signature of global actions to tackle climate change.

In order to limit climate change well below $2{ }^{\circ} \mathrm{C}$, our emissions must follow a decreasing trajectory to near zero. A large number of scenarios consistent with the two-degree limit include technologies that can actually capture $\mathrm{CO}_{2}$ out of the atmosphere and store it below ground. These so-called negative emissions rely on unproven technologies and are in competition with agriculture. They are not a safe bet [3]. At the other extreme, scenarios based on intense use of fossil fuels lead to very high climate change-with a range of related high risks in addition to warming, for example risks of floods from sea level rise and increased heavy rainfall, stress on access to drinking water from salt-water contamination, and droughts, and a range of associated health risks.

What are we expecting from the Paris Agreement on climate change? On the one hand, we have what the countries bring, the 'NDCs' for Nationally Determined Contributions. The implementation of the NDCs as they stand would lead to an increase of around $3{ }^{\circ} \mathrm{C}$, somewhere between the $1{ }^{\circ} \mathrm{C}$ we are already observing and a planet with a very risky climate future. But the Paris Agreement does set clear ambitions to keep the warming well below $2{ }^{\circ} \mathrm{C}$ and to pursue efforts to limit the warming to $1.5{ }^{\circ} \mathrm{C}$, with a roadmap revision for each country every 5 years. There is a conflict between the promised contributions and the level of ambitions, and the outcome for future warming will depend on what individual countries will do next.

We have been working with the World Health Organization (WHO) and other institutes worldwide to do a country-by-country analysis of the implications of climate change [4]. We compared recent temperature observations with warming projections over the country, so people can see the consequences of climate change in their own context. They can relate what a projection of a global temperature rise below $2{ }^{\circ} \mathrm{C}$ implies for them compared to a future would in a high-risk climate change. I have spoken a great deal about average temperature, but changes in climate extremes could have the greatest impact on health. Changes in climate extremes have been summarised in a table of the Intergovernmental Panel on Climate Change (IPCC) [5] and the WHO report [4]. Three extremes are particularly clear and well documented: increases in heat waves, increases in intense precipitation (rainfall and snowfall), and increases in sea level and storm surges. The last two have associated increased risks of floods. All have associated risks for food production and possibly pests and disease outbreaks. Even when limiting climate change to $2{ }^{\circ} \mathrm{C}$, understanding regional impacts and adapting to a changing climate will be essential.

\section{Conclusion}

A wise way to respond to the current state of knowledge on climate change would be to prepare to deal with a high-risk climate change future, but to work to mitigate climate change well below $2{ }^{\circ} \mathrm{C}$ by reducing global emissions to zero. Adopting this 
double strategy could help prepare for all eventualities, while working for the outcome with the lowest risks for current and future generations.

\title{
Abbreviations \\ INDCs: Intended Nationally Determined Contributions; IPCC: Intergovernmental Panel on Climate Change; WHO: World Health Organization
}

\section{Acknowledgements}

I thank Clare Goodess and Colin Harpham who did most of the analysis of the climate data in the Climate change and Health Country profiles presented here, which was funded by the Wellcome Trust.

Funding

Not applicable.

\section{Availability of data and materials}

Not applicable.

\section{Author's information}

Corinne Le Quéré is a Professor of Climate Change Science and Policy at the University of East Anglia and a Director of the Tyndall Centre for Climate Change Research. She authored the third, fourth, and fifth Assessments of the Intergovernmental Panel on Climate Change, which was awarded the 2007 Nobel Peace prize. She was awarded the Claude Berthault award from the French Academy of Science and was elected Fellow of the UK Royal Society in 2016.

\section{Competing interests}

The author declares that she has no competing interests.

\section{Consent for publication}

Not applicable.

\section{Ethics approval and consent to participate}

Not applicable.

Received: 20 September 2016 Accepted: 26 October 2016

Published online: 05 December 2016

\section{References}

1. Le Quéré C, Moriarty R, Andrew RM, Canadell JG, Sitch S, Korsbakken Jl, et al. Global carbon budget 2015. Earth Syst Sci Data. 2015;7:349-96. doi:10.5194/essd-7-349-2015.

2. Jackson RB, Canadell JG, Le Quéré C, Andrew RM, Korsbakken JI, Peters GP, Nakicenovic N. Reaching peak emissions. Nat Clim Chang. 2016;6:7-10.

3. Smith P, Davis $\mathrm{S} J$, Creutzig F, Fuss $\mathrm{S}$, et al. Biophysical and economic limits to negative $\mathrm{CO}_{2}$ emissions. Nat Clim Chang. 2015;6:42-50.

4. World Health Organization and United Nations Framework Convention on Climate Change. Climate and health country profiles-2015. A global overview. 2015. http://www.who.int/globalchange/resources/countries/en/.

5. IPCC, 2013: Climate change 2013: the physical science basis. Contribution of working group I to the fifth assessment report of the Intergovernmental Panel on Climate Change [Stocker, T.F., D. Qin, G.-K. Plattner, M. Tignor, S.K. Allen, J. Boschung, A. Nauels, Y. Xia, V. Bex and P.M. Midgley (eds.)]. Cambridge University Press, Cambridge, United Kingdom and New York, NY, USA, 1535 pp. doi:10.1017/CBO9781107415324

\author{
Submit your next manuscript to BioMed Central \\ and we will help you at every step: \\ - We accept pre-submission inquiries \\ - Our selector tool helps you to find the most relevant journal \\ - We provide round the clock customer support \\ - Convenient online submission \\ - Thorough peer review \\ - Inclusion in PubMed and all major indexing services \\ - Maximum visibility for your research \\ Submit your manuscript at \\ www.biomedcentral.com/submit

